\title{
4. Government Shipbuilding
}

Naval construction, together with the production of ordnance, takes a special position among the branches of production in which the Qing state engaged actively. They constitute central elements in the transition to the mechanization and industrialization of the Chinese economy in the second half of the nineteenth century. For the basic hypothesis of this study - the relative efficiency of craft and industrial administration by the Qing state over its entire duration - we will first explore the achievements of the state in ship construction.

One of the central tasks that any government must fulfil is to provide the basic supplies for the government, its officials, and its military as well as border defence and the maintenance of internal order. In the imperial Chinese state, devices for the transport of provisions and of armed forces were considered to be so strategically important that the only option was to produce them in institutions under direct government control. Therefore, state shipyards at fluvial and sea harbours were operated and managed by the ministries responsible for Public Works, Finances and the Military. However, ship construction both for grain transport and the fluvial and naval forces receded in output and efficiency from its highest levels in the early eighteenth century until the period of interior and exterior cataclysms of the Taiping rebellion and the Opium Wars.

When the military crises of the nineteenth century took place, together with the financial predicament of the central government and the disaster of the Yellow River flooding, substitutes for the grain transport vessels and the favoured transport route on the Grand Canal had to be found. Grain shipping was first transferred to commercial shippers and later to the first 'merchant managed and officially supervised' China Merchants' Steam Navigation Company (CMSNC). With regard to the marine forces, the security of the Qing dynasty and its sovereignty was threatened from overseas by faster ships and more destructive weapons. Although the Qing state soon acquired such vessels and military materiel from abroad, top officials felt uneasy about the paradoxical situation of having to rely on potential and real enemies to provide weapons and military transport facilities for the country's national defence.

The court faction around Prince Gong (Yixin 1840-1891), the founder of the Office of Foreign Affairs (Zongli yamen) saw this danger and agreed to the demands of the high-ranking provincial officials and military men, Zeng Guofan, Li Hongzhang, and Zuo Zongtang, to set up arsenals and shipyards in Western style. The aim of this so-called self-strengthening (ziqiang) programme was to learn the techniques of mechanical production in the military sector as 
quickly as possible to reach a level of self-sufficiency within a few years. What were the achievements and the failures of government shipbuilding in the early and mid-Qing and during the period of self-strengthening? With a view to the thesis of the relative efficiency of the Qing, we will look at the output and financing in naval construction and explore the organization of government shipyards before and after the advent of steam navigation. In chapter five, this will be set against the activities of private shipyards so as to come to an estimate of the relative size of both sectors and their relationships and interdependence.

\section{Government Shipbuilding in the Civilian Sector: Grain Tax Shipment and Organization}

Within the system of taxation, the rice growing regions in Jiangsu, Zhejiang, Anhui, Hubei, Hunan, Shandong, and Jiangxi were subjected to a special imperial grain tax. This so-called tribute rice and other natural produce in smaller quantities, such as millet and beans, timber, mats, and bamboo, were shipped on the Grand Canal to the capital to supply the court, the officials of the central government, and the troops stationed in Peking. Since Peking lies about one thousand kilometres north of the abundant rice regions, considerable logistical efforts were necessary to achieve this task. As Harold Hinton has aptly formulated, grain tribute 'occupied a position particularly close to the hearts and stomachs of the emperors and their courts. ${ }^{1}$

\section{Table 17 Volume of tribute grain shipment in the early nineteenth century}

\begin{tabular}{ll}
\hline $\begin{array}{l}\text { Grains collected } \\
\text { Thereof }\end{array}$ & ca. 6.2 mio shi $(443,300$ tons) \\
$\begin{array}{l}\text { Grains used for covering the costs of collection, } \\
\text { transport, and storage }\end{array}$ & ca. 2.8 mio shi ( 200,200 tons) \\
$\begin{array}{l}\text { Grains that reached the Peking granaries } \\
\text { From the grains that reached the Peking granaries }\end{array}$ & ca. 3.4 mio shi $(243,100$ tons) \\
$\quad \begin{array}{l}\text { Salaries in kind for court, nobility, officials } \\
\text { Military provisions for soldiers in the capital }\end{array}$ & ca. 0.4 mio shi ( 28,600 tons $)$ \\
$\quad \begin{array}{l}\text { Sacrificial use, gruel stations, sales on } \\
\text { open market for stabilizing food prices }\end{array}$ & ca. 2.4 mio shi $(171,600$ tons $)$ \\
$\begin{array}{l}\text { For comparison } \\
\text { Grains that reached Peking granaries, early Qing }\end{array}$ & ca. 0.6 mio shi ( 42,900 tons) \\
\hline
\end{tabular}

Source: Based on data from Leonard, Controlling from Afar, pp. 98-99. 
Figure 1 Grain transport ship, Caofang chuan
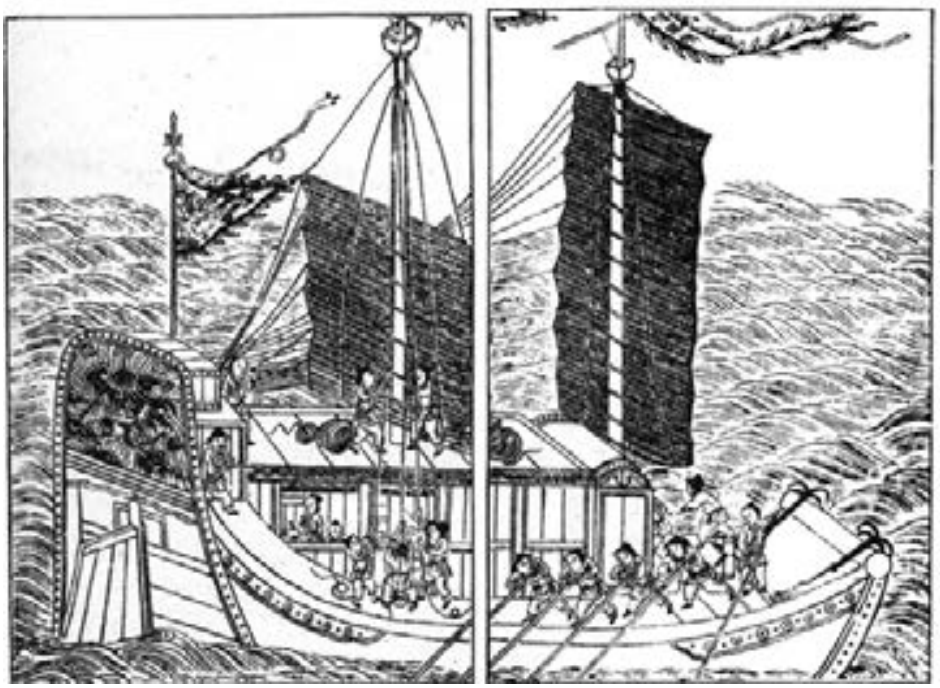

Source: Qing illustration to the late Ming text Tiangong kaiwu by Song Yingxing (1637), p. 178.

In the Ming dynasty, which since 1420 had also established their capital in Peking, grain transport had been handled by the military, and state shipyards had built the grain transport ships (see Figure 1). The measurements of these two mast ships were an average length of 18 to 26 metres and had a width of 3 to 3.4 metres. The cargo-carrying capacity was about 2,000 shi $[140$ tons $] .^{2}$

This system was essentially taken over by the Qing.Together with taking care of the general tax grain administration, the provinces were also responsible for the construction and maintenance of the vessels. Grain boat captains and crews were selected from a group of hereditary tenants on military colonies (tuntian). Between the late seventeenth and the early nineteenth century, the number of state ships and crews decreased by approximately 43 percent as the volume of tribute grain diminished. ${ }^{3}$

2 Leonard, Controlling from Afar, pp. 103-4. Huidian, chap. 935, fol. 3 b (Kangxi 22, 1683) gives the 'new pattern' to which the grain ships of all provinces should conform: 7.1 zhang (22.72 m) length and 1.44 zhang $(4.60 \mathrm{~m})$ width. However, subsequent sections of the chapter discuss various deviations from this model. The smaller-sized lighters (bochuan) ranged in lengths from ${ }_{18.5} 6$ $\mathrm{m}$ (Tianjin) and $16.96 \mathrm{~m}$ (Shandong) to $14.4 \mathrm{~m}$ (Jiangsu) and widths of $3.54 \mathrm{~m}$ (Tianjin), $3.84 \mathrm{~m}$ (Shandong), and $2.94 \mathrm{~m}$ (Jiangsu) and eight to nine holds (specifications in Huidian, chap. 935, fol. $7 \mathrm{~b}, 9 \mathrm{~b}, 11 \mathrm{~b}$ for Tianjin 1786 and Shandong and Jiangsu 1788).

3 Hinton, Grain Tribute System, pp. 11-12. 
Table 18 Quotas for the number of grain transport ships in the grain-providing provinces

\begin{tabular}{|c|c|c|c|}
\hline Province & $\begin{array}{l}\text { Original } \\
\text { quotas in the } \\
\text { early Qing }\end{array}$ & $\begin{array}{l}\text { Reduced } \\
\text { quotas } \\
(1812)\end{array}$ & Remarks \\
\hline Zhili & 39 & 37 & \\
\hline Shandong & 1,054 & 887 & $\begin{array}{l}\text { Thereof } 361 \text { official, } 185 \text { self- } \\
\text { organized (zibei) ships; those } \\
\text { who transported for Shandong: } \\
646 \text {; those who assisted the } \\
\text { transport of Henan: } 241\end{array}$ \\
\hline $\begin{array}{l}\text { Jiangnan Jiang'an grain } \\
\text { circuit }\end{array}$ & 4,887 & 2,696 & $\begin{array}{l}\text { Including } 97 \text { who assisted the } \\
\text { transport of Henan }\end{array}$ \\
\hline $\begin{array}{l}\text { Jiangnan Su-Song grain } \\
\text { circuit }\end{array}$ & 648 & 522 & \\
\hline Zhejiang & 1,999 & 845 & \\
\hline Jiangxi & 1,002 & 638 & \\
\hline Huguang (Hubei and Hunan) & 886 & 358 & \\
\hline TOTAL & 10,515 & 5,983 & \\
\hline
\end{tabular}

Source: Huidian shili, chap. 202, fol. 1b.

From the late eighteenth century onward, the junction of the Grand Canal and the Yellow River became so silted that the traffic from the Yangzi Delta to the capital was slowed down or at times even blocked. Inland transport was maintained by using small-size lighter boats (bochuan) upon the entire Grand Canal or at least for certain stretches. ${ }^{4}$ The southern provinces were also admonished time and again to downsize their regular grain ships. This can be seen from the references in the Collected Statutes presented in Table 19, which documents the government norm measurements. ${ }^{5}$

4 Leonard, Controlling from Afar, p. 39, 48, 49, 102, and 'Timeliness and Innovation' p. 454, $459 \mathrm{ff}$., where she points out the three options described in the government regulations on Canal shipping: transfer shipment, which 'included the cart haulage of the cargoes over the south bank of the Yellow River to waiting lighters that ferried the grain across the river for northward transport to the capital' (op. cit., p. 454), sea transport and lock transport, which used a hydraulic device to send the grain ships over the Grand Canal - Yellow River junction. Huidian, chap. 935, fol. $7 \mathrm{~b}, 9 \mathrm{~b}$, 11b specifies the measurements for 1786 (Tianjin) and 1788 (Shandong and Jiangsu), with lengths ranging from $18.56 \mathrm{~m}$ (Tianjin) and $16.96 \mathrm{~m}$ (Shandong) to $14.4 \mathrm{~m}$ (Jiangsu), and widths of $3.54 \mathrm{~m}$ (Tianjin), $3.84 \mathrm{~m}$ (Shandong) and 2.94 $\mathrm{m}$ (Jiangsu).

5 Huidian shili, chap. 935, fol. 14 b. 
Table 19 Grain ship sizes

\begin{tabular}{|c|c|c|c|c|}
\hline $\begin{array}{l}\text { Date and reference } \\
\text { in Collected Statutes } \\
\text { (Huidian shili) }\end{array}$ & Province & Length & Width & $\begin{array}{l}\text { Depth of } \\
\text { holds }\end{array}$ \\
\hline $\begin{array}{l}\text { Kangxi } 22 \text { (1683), } \\
\text { chap. } 935, \text { fol. } 3 b\end{array}$ & $\begin{array}{l}\text { 'All } \\
\text { provinces' }\end{array}$ & 7.1 zhang/22.72 m & $\begin{array}{l}1.44 \text { zhang/ } \\
4.60 \mathrm{~m}\end{array}$ & \\
\hline $\begin{array}{l}\text { Kangxi } 52 \text { (1713), } \\
\text { chap. } 202 \text {, fol. } 5 b\end{array}$ & $\begin{array}{l}\text { Jiangxi and } \\
\text { Huguang }\end{array}$ & $\begin{array}{l}\text { Between } 9 \text { and } 10 \\
\text { zhang }(28.8-32 \mathrm{~m}) \text {, } \\
\text { normally } 10, \text { never less } \\
\text { than } 9\end{array}$ & & \\
\hline $\begin{array}{l}\text { Qianlong } 50 \text { (1785), } \\
\text { chap. 202, fol. 21b }\end{array}$ & $\begin{array}{l}\text { Henan and } \\
\text { Shandong }\end{array}$ & $\begin{array}{l}\text { 'smaller' than in the } \\
\text { southern provinces }\end{array}$ & & \\
\hline $\begin{array}{l}\text { Qianlong } 50 \text { (1785), } \\
\text { chap. 202, fol. 21b/22a }\end{array}$ & $\begin{array}{l}\text { Zhejiang } \\
\text { and } \\
\text { Jiangnan }\end{array}$ & 8 zhang/25.6 m & $\begin{array}{l}1.5 \\
\text { zhang/4.8 m }\end{array}$ & $\begin{array}{l}0.6 \\
\text { zhang/1.92 m }\end{array}$ \\
\hline $\begin{array}{l}\text { Qianlong } 50 \text { (1785), } \\
\text { chap. 202, fol. 21b/22a }\end{array}$ & $\begin{array}{l}\text { Jiangxi and } \\
\text { Huguang }\end{array}$ & 9.5 zhang/30.4 m & $\begin{array}{l}1.65 \\
\text { zhang/5.28 m }\end{array}$ & $\begin{array}{l}0.69 \\
\text { zhang/2.2 m }\end{array}$ \\
\hline $\begin{array}{l}\text { Jiaqing } 15 \text { (1811), } \\
\text { chap. 202, fol. } 25 \text { a }\end{array}$ & $\begin{array}{l}\text { Jiangxi and } \\
\text { Huguang }\end{array}$ & 9 zhang/28.8 m & $\begin{array}{l}1.65 \\
\text { zhang/5.28 m }\end{array}$ & $\begin{array}{l}0.66 \\
\text { zhang/2.11 m }\end{array}$ \\
\hline
\end{tabular}

In 1826 and 1847 , experiments with grain transport by sea were carried out. Sea shipment was organized by private merchants. ${ }^{6}$ In the 1850 s, the Yellow River changed its bed so that its estuary no longer lay south but north of the Shandong peninsula. This caused enormous floods and made traffic from the regions south of the Yangzi to Tongzhou altogether impossible. Moreover, the regions near the junction of the Grand Canal and the Yellow River lay in the territory of the Taiping rebels and thus out of the control of the central government. Therefore, from 1851 onward, the tribute grain that was still being sent to the capital was shipped entirely by merchants via the sea route from the Yangzi Delta to Tianjin. Such new developments temporarily benefited some safer regions, such as Ningbo in Zhejiang. The concerned shipping merchants cooperated (and competed) in the so-called associations of the 'Northern' bei hao' and the 'Southern ship traders' nan hao, the Northerners hailing from Jiangnan and Shandong, the Southerners from Fujian and Guangdong, with local Ningbo people represented in both associations. ${ }^{7}$ These groups had already participated in the 1826 experiment with sea transport, employing 130 merchant ships of the 'Northern ship traders' to Tianjin, and between 10,000 and 20,000 weighing masters, dock

6 Huidian shili, chap. 935, fol. 17b/18a (Daoguang 2, 1822). Leonard, Controlling from Afar, p. 39 ff.; Ni Yuping, 'Caoliang haiyun', p. 125.

7 Shiba Yoshinobu,' Ningpo and Its Hinterland', p. 399. 
workers, porters, shipwrights, and sail and rope makers at Ningbo harbour. ${ }^{8}$ In the 1850 s, as Zhejiang delivered 600,000 to 700,000 shi of grain to the north, sea trade and shipbuilding boomed again. The cargo was delivered on board flat bottomed sand ships ${ }^{9}$ (Figure 2) and the typical Ningbo 'egg ships', ${ }^{10}$ but the changed strategic situation also prompted the trading companies to acquire, for 70,000 tael, the steam ship Baoshun as a security escort for their northbound vessels. ${ }^{11}$

After the Taiping rebellion was defeated, and as foreign competition in sea transport increased, ship trade and shipbuilding in Ningbo entered into a decline. Only 400 of the original 3,000 sand ships reported in the 1840 s still existed in 1867 , and the number of egg ships in the possession of the northern ship traders dropped from 200 to 100 after $1864 .{ }^{12}$

8 Ni Yuping, 'Caoliang haiyun', p. 2, referring to Duan Qingguang 段清光, Jinghu zizhuan nianpu 鏡湖自撰年譜 (Jinghu's autobiographical chronology).

9 'Sand ships' (Shachuan) were named after their region of origin, the Chongming islands or sands in the Yangzi estuary (Zhonghua wenhua jingcui fenlei cidian, p. 599). An alternative etymology is that these ships were suitable for sailing in shallow coastal waters, sandbanks, and shoals. Sand ships were mainly constructed in the Yangzi delta area and in coastal regions north of it. They were used for coastal and open sea transport as well as the interface between fluvial and marine transport. They had a flat U-shaped bottom, a low draft between 0.7 and 2.5 metres, and were most often sized about 30 by 6 metres, with a loading capacity of several hundred metric tons (Deng Gang, Chinese Maritime Activities, p. 29). Their bow and stern were both square. They were slower than keeled ships but could still reach acceptable speeds because of their shallow draft and their many sails on multiple masts (Fang Zhuofen et al., 'Shanghai Maritime Shipping', p. 359). Sand ships were made of Chinese fir (shamu) or pine (songmu) timber (Xu Jianqing, Qingdai qianqi, p. 594; Scheuring, Drachenfluß-Werft, p. 129, identifies shamu as Cunninghamia lanceolata.) A vessel of this type was still found circulating at Wusong in Jiangsu province by researchers of the Shanghai Digital Ship Museum in 2002. For the richly illustrated documentation of this research, see the relevant pages of the Digital Ship Museum of Jiaotong University, Shanghai: http://shipmuseum.sjtu.edu.cn/shachuan/shachuaninfo.htm.

10 The so-called 'egg ships' (danchuan) form an intermediary type between the flat bottom and the V-shaped ocean-going keel vessels. Deng Gang in Chinese Maritime Activities, p. 29, introduces it as the third most basic type of Chinese sailing ships. The ship originates from Ningbo and is commonly also referred to as 'Ningbo junk' (Sun Wujun, 'Zhongguo diyi sou lun'). This type was adapted for sailing the shallow sea waters to the north as well as the greater depths to the south of Ningbo. It was used for overseas grain transport after 1826 (Ni Yuping, 'Caoliang haiyun', p. 125).

11 Ni Yuping, 'Caoliang haiyun', p. 126, referring to Zhejiang haiyun quan'an xinbian 浙江海運 全案新編 (New edition of the complete archives of Zhejiang sea transport), chap. 6, 'Fangyang xunhu shiyi' 放洋巡護事宜 (Requirements and organization of security for seafaring).

12 Ni Yuping, 'Caoliang haiyun', p. 127, referring to Chouban yiwu shimo (Tongzhi chao) 籌辦夷 務始末, 同治潮 (The management of barbarian affairs, from A to Z. Tongzhi era), chap. 28 (for sand ships) and Haifang dang. Goumai chuanpao (3) 海防檔, 購買船炮 (3) (Coastal defence archives: Acquisition of ships and cannons), ed. Zhongyang yanjiuyuan, 1957, p. 816. 
Figure 2 Sand ship, Shachuan

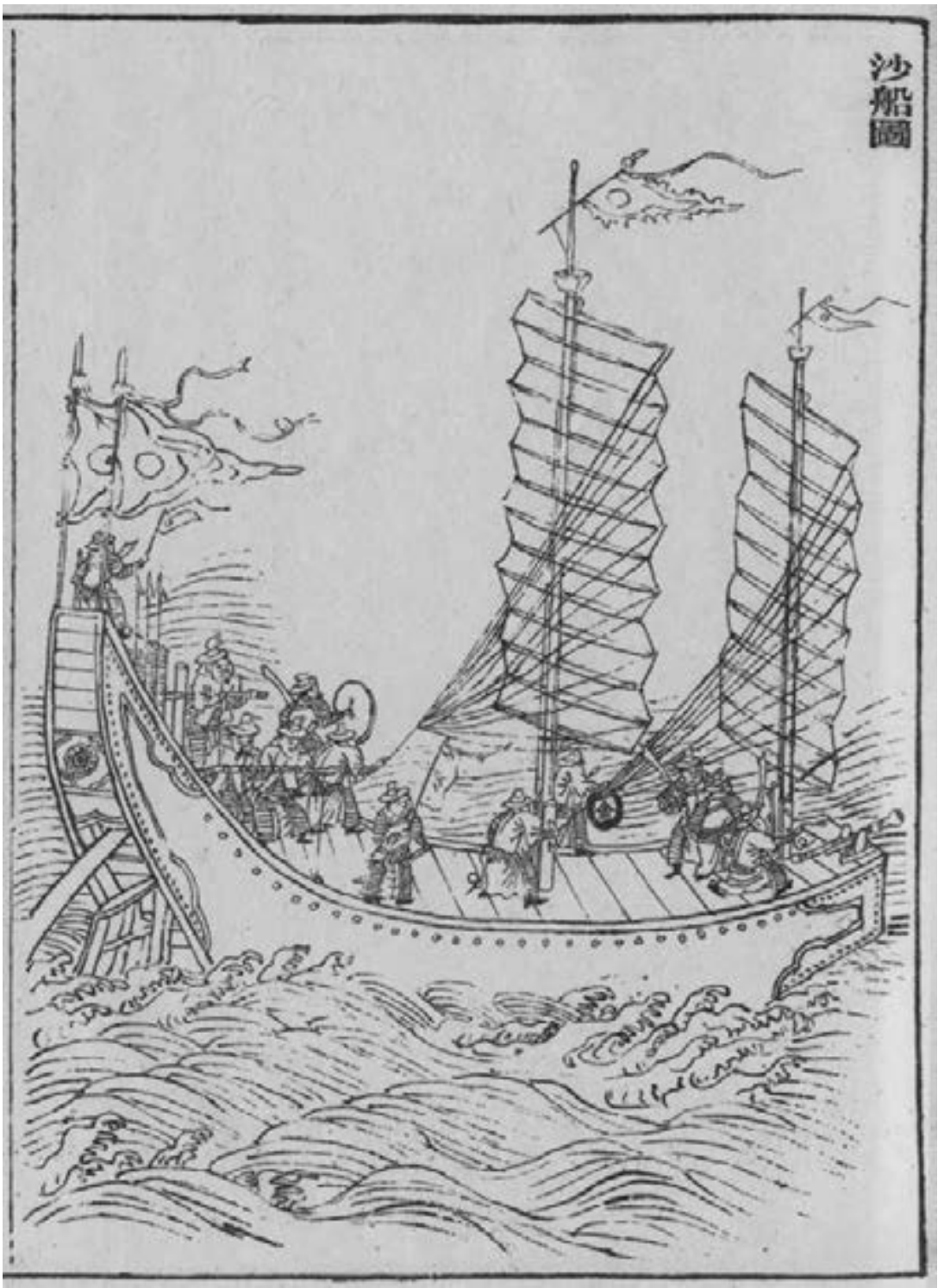

Source: Illustration in the encyclopedia Gujin tushu jicheng (1726), reprint 1884, section 'Jingji huibian' 經濟彙編 (Collection on governance), 'Rongzheng dian' 戎政典 (Military administration), 'Shuizhan bu' 水戰部 (Naval warfare), 'Huikao' 彙考 (Extracts from standard works), chapter 79, fol. $8 a / 2$ (in 1964 reprint, vol. 749, p. 9/2). 
The Qing government was now in a dilemma as to how to reorganize grain transport. Grand Canal transport was possible only on certain stretches, but most of the grain ships had been destroyed during the war. In 1866 the Shanghai Customs Intendant Ying Baoshi suggested that the court either buy up all available seagoing sand ships or, as he petitioned in 1869, acquire foreign sailing ships (jiabanchuan) $)^{13}$ for the grain transport. However, both options as well as steamship transport were deemed too costly for the Qing state. Until 1873, about one million shi of the tribute, only one half of the pre-Taiping quotas, was shipped to Tianjin in chartered private sailing ships and from there to Tongzhou by lighters. ${ }^{14}$ Eventually, the Governor-General of Zhili province, Li Hongzhang (1823-1901), succeeded in promoting the China Merchants' Steam Navigation Company (CMSNC) in 1872. This was the first company under 'official supervision and merchant management' (guandu shangban), which implied special government protection and control and mainly merchant capitalization. Li Hongzhang made arrangements to let this company - the literal Chinese designation implies a 'government bureau promoting merchant [engagement] in steam navigation' rather than a 'company' - organize the shipment of grain tribute. At first, despite its name, its fleet consisted not only of steamships, but started out with a ratio of 80 percent sand ships and 20 percent steam ships. This was later changed to sixty percent sand ships and forty percent steam ships. In 1877, Li Hongzhang decided that 40 to $5^{\circ}$ percent of the grain tribute from Zhejiang and Jiangsu must be transported by steamship. In order to fight foreign competition, the CMSNC bought up the two biggest foreign shipping firms including their steamships, docks, and administrative buildings in Shanghai: the Shanghai Steam Navigation Company (Qichang), founded in 1862, the first domestic steam shipping company ever to be established in China; and the English Butterfield and Swire Company (Taigu or Taikoo), founded in $1866 .^{15}$ The business form of government control and merchant management was and still is seen as a downright failure, or at least is heavily criticised for its many shortcomings, especially in comparison to the achievements of the foreign competitors (see Table 23). ${ }^{16}$ Yet the CMSNC successfully, and from 1902 onward

\footnotetext{
13 jiabanchuan, 'double-plank ship', see Xin Yuan'ou, Zhongguojindai, p. 6.

14 Hinton, Grain Tribute System, p. 90, 99.

15 This is Ni Yuping's version of the events in 'Caoliang haiyun', p. 126. Liu Kwang-ching, 'Steamship Enterprise', p. 440, only mentions the takeover of Russell \& Co.'s Shanghai Steam Navigation Company in 1877 . According to Liu Kwang-ching, op cit., p. 448 , in 1883 the CMSNC acquired eight steamships from the China Navigation Company, under the agency of Butterfield and Swire, but the latter remained an - eventually more successful - competitor.

16 Liu Kwang-ching, 'Steamship Enterprise', pp. 452-4.
} 
exclusively, handled the tax grain shipment until the system was abolished in early 1911. Since the transport canal Beihe that links Tianjin and Tongzhou also became heavily silted and was hardly navigable after 1894, lighterage once more became a problem and was given up after 1902, when the last part of the journey was covered by railway. Before the twentieth century, the CMSNC did not allow Chinese competitors into the market, but with government backing ensured that it retained at least the Chinese transport monopoly throughout the nineteenth century. ${ }^{17}$

For our context, it is important to note that the company did not actively promote shipbuilding. It bought its vessels mainly from foreign manufacturers at Shanghai and Hong Kong. ${ }^{18}$ However, in 1874 it initiated the foundation of a maintenance and repair company for the CMSNC ships that was capitalized by merchants and operated formally as an independent company under the name Tongmao but de facto probably was a spin-off under 'official control' like the CMSNC. At first, all its workers and technicians were Chinese, but after two years, foreigners were called in for assistance. At its own repair shipyard in the Shanghai industrial quarter Hongkou, all the machinery was steam powered. Due to mismanagement, it had to be closed down in 1879 and was then taken over as a private company by a previous staff member of the CMSNC. Besides repair, in the 188os, six small iron hull steamers were constructed here, but it also was closed down again in $1886 .{ }^{19}$

The Qing management of tribute grain shipment, including the construction of the needed ships, exemplifies the options and the dilemmas of a large empire upon the threshold of industrialized, fossil-fuelled transportation. Turning to ship construction for military purposes, the emerging picture becomes even clearer. For this purpose, it is necessary to turn back to the early days of Qing administration.

\section{Government Shipbuilding in the Military Sector: Construction of Sailing Ships for the Naval Forces}

Until the late nineteenth century, the Qing armed forces consisted of the two large units known as 'Eight Banners' and 'Green Standards'. The Eight Banners

17 Ibid. p. 453 .

18 Cornet, Etat et entreprises, p. 41. However, Pong, Shen Pao-chen, p. 236, states that in early 1874 , three vessels of the Fujian Navy Yard were turned over to the China Merchants' Steam Navigation Company.

19 Xin Yuan'ou, Zhongguojindai, p. 205. 
were composed of Manchu, Mongols, and Han Chinese who had surrendered early to the Manchus, while the 'Green Standards' formed the provincial troops with a soldiery of surrendered Ming men. In the eighteenth century, the standing troops totalled about 200,00o bannermen and 660,00o Green Standard troops. ${ }^{20}$ The marine forces shuishi belonged to the Green Standards and thus not to the core troops under the direct command of the emperor or imperial princes. Like all Green Standard units, they constituted 'a kind of provincial constabulary, or a ready reserve force' and were formally subject to the administrative jurisdiction of the Ministry of War but actually came under the actual control of provincial civilian administrators (governors and governors-general) and military commanders (tidu) in each province. ${ }^{21}$

The administrative control by the Ministry of War implied that the number, quality, construction, and maintenance of marine ships were supervised by that ministry and, as far as technical matters were concerned, the Ministry of Public Works, which in cooperation with the Ministry of Revenue also formally decided on funds to be allocated to the provinces for their marine equipment. The actual shipbuilding was carried out in provincial shipyards.

The activities and attitudes of the central government and the provincial administrations toward defensive shipbuilding are reflected in the chapters of the Collected Statutes of the Qing Dynasty with Factual Precedents, Qinding Da Qing huidian shili (1899, hereafter Huidian shili), concerning the Ministry of Public Works. ${ }^{22}$ The chapters of the Ministry of War include the overall figures of government ships for the situation of about 1880 and original quotas of the early eighteenth century.

Table 20 Quotas for coastal and fluvial guard and patrol ships of all sizes

\begin{tabular}{lcccl}
\hline Province & $\begin{array}{l}\text { 'Original quotas' } \\
\text { (ca. 1736) }\end{array}$ & $\begin{array}{l}\text { 'Actual figures', } \\
\text { ca. 1880 }\end{array}$ & $\begin{array}{l}\text { Remarks } \\
\text { Shengjing }\end{array}$ Not mentioned $^{\text {Not mentioned }}$ & $\begin{array}{l}\text { Relation } \\
\text { (ca. 1736= 100) }\end{array}$ \\
Zhili & 12 & 50 & & \\
Shandong & 575 & 20 & & 166.67 \\
Jiangsu & & 684 & Thereof 2 & 118.96 \\
& 82 & 332 & steamships & \\
Anhui & 39 & 185 & & 404.88 \\
Jiangxi & & & & 474.36
\end{tabular}

20 For a discussion of the statistical evidence, see Moll-Murata and Theobald, 'Military employment in Qing dynasty China', pp. 346-349.

21 Hucker, Dictionary of Official Titles, p. 91.

22 Huidian shili, chap. 936-938. 


\begin{tabular}{lcccl}
\hline Province & $\begin{array}{l}\text { 'Original quotas' } \\
\text { (ca. 1736) }\end{array}$ & $\begin{array}{l}\text { 'Actual figures', } \\
\text { ca. 1880 }\end{array}$ & Remarks & $\begin{array}{l}\text { Relation } \\
\text { (ca. 1736 = 100) }\end{array}$ \\
\hline Fujian & 394 & 81 & 20.56 \\
Zhejiang & 471 & 469 & 99.58 \\
Hubei & 86 & 200 & 232.56 \\
Hunan & 70 & 68 & 97.14 \\
Guangdong & 705 & 349 & Thereof 22 & 49.50 \\
& & & steamships \\
Total & 2,434 & $2,448^{1}$ & & 100.01 \\
\hline
\end{tabular}

Source: Huidian shili, chap. 712 , fol. 1a-7a.

${ }^{1}$ Note the difference of 247 ships less in the statistics given by Worcester, Junks and Sampans, p. 612, 'Chinese War Vessels and their Stations', which he quoted from The Chinese Repository, vol. 20 (1851), p. 379.

In these statistics, the grand total remain virtually unchanged, yet the quotas for several provinces showed a large increase (for the inland provinces Anhui, Jiangxi, and Hubei). There was also a moderate increase for the coastal Zhili and Shandong provinces, a slight decrease for the coastal Zhejiang and inland Hunan, and a large decrease for Guangdong and Fujian, the most sea-oriented of all the provinces. To embed this evidence, four distinct phases of defensive shipbuilding can be discerned from the compilation of edicts and memorials that were exchanged between provincial officials, the central government, and the emperors (and their edict writers).

\section{Phase 1: Initial reconstruction and succession of the Ming System, ca. $1675^{-1722}$}

In the middle and late Kangxi era, especially after the maritime empire of Zheng Chenggong (Coxinga) on the southeastern coast and Taiwan had been defeated in 1683, the Qing actively established coastal defence according to the model of the Ming. Supervision and organization of shipbuilding was delegated to the provinces and their shipyards (see Table 21). The methods of financing by the provinces and norm prices of ships were laid out. The cycle of shipbuilding was a small overhaul after three years, a large one after five years, and if the ships were still usable after another five years, another general overhaul. ${ }^{23}$ When ships were broken up, the utilizable materials were to be recycled and built into the new ships.

23 Huidian shili, chap. 936, fol. 1 (Kangxi 13, 1674). In Kangxi 29 (1690) this pattern was modified into a small overhaul after three years, a big overhaul after six years, and if the ship was still 


\section{Phase 2: Expansion and consolidation, 1723-ca. $175^{\circ}$}

Although there were problems in the financing and timing of the repairs, a conviction that such issues could be solved by methods of extra subsidies and moral exhortation underlies the memorials and edicts of the Yongzheng and early Qianlong period.

\section{Phase 3: Reorganization, fleet reductions, and downsizing of ships, ca. 1750-1840}

Despite government sanctions and guidelines, the situation did not improve. In the next phase, for about ninety years from the mid-eighteenth century to 1840 , major reshuffles and a reorganization of navy and fluvial marine vessels took place. The first cry of alarm came in 1759, when the central government was no longer sure whether the situation could be remedied by increased care in carrying out overhauls and reconstructions. The emperor commented on a memorial stating that for the spring drills at the Chongming marine station in Jiangsu, only five patrol ships were present. The ships of the other marine patrol stations were all at the shipyard for repair. ${ }^{24} \mathrm{~A}$ similar incident occurred in 1817, when a censor found out that in the Jiaozhou bay in Shandong, some ships had remained in the shipyard for between eight and ten years, waiting for overhauls. ${ }^{25}$

Therefore the Collected Statutes of this period abound with information on reductions of battleships from the official vessel registers or replacement by other, more economic or more efficient ship types. ${ }^{26}$ Officials repeatedly proposed to rebuild the battleships in the form of merchant ships, since the latter were found more suitable for chasing pirates. The emperor and central government were aware that merchant ships lasted at least twice as long as battleships, ${ }^{27}$ but this was to a large extent due to the unsatisfactory maintenance of the state ships. However, not everybody was convinced that downsizing the ships would solve the problem. In 1790, government

functional after nine years, another big overhaul; if not, it was broken up and reconstructed with part of the usable material. For the fluvial marine, a small overhaul after nine years was provided, but the rest of the maintenance procedure was the same.

24 Huidian shili, chap. 937, fol. 1a.

25 Ibid., fol. $20 a$.

26 The first relevant record states that in 1754 the ten ships of the Lüshun marine patrol station in Fengtian province were reduced to four. Huidian shili, chap. 937, fol. 1b.

27 Huidian shili, chap. 936, fol. 14b, edict Qianlong 13 (1748). 
officials in Guangdong province memorialized that sea marine ships had to be sturdy enough for numerous troops and ordnance. They should not all be constructed like merchant ships, because chasing pirates was not their only purpose. ${ }^{28}$

\section{Phase 4: Crisis, reform, and modernization, 1840-1911}

The shock of the First Opium War (1839-1842), which started out and was decided at sea, prefigured the last phase of official shipbuilding (1840-1911). It can again be subdivided into a phase of disillusioned assessment of the current situation, an episode of the commitment of local elites, and after 1865 , reform efforts as proposed by provincial administrators with varying support and funding by the central government. In 1844, a sober account of the situation of the Jiangnan fleet states that of its 275 ships, none was actually well maintained. It was suggested that their number should be reduced to 135 and that they should all be repaired at the Jiangnan and Suzhou shipyards at market prices (shijia 市價). ${ }^{29}$ The total costs of 357,102 tael for one ten-year cycle of maintenance, 2,645 tael per ship, were to be covered by the districts and the province of Jiangnan..$^{30}$ In the case of the Fujian fleet, the Ministry of Public Works informed the province that if Fujian raised the funds for shipbuilding, the ministry would cover the costs for cannons and guns. ${ }^{31}$

The Cantonese population was the most exposed to new developments in Western warfare and transport, and after the controversies on the opium trade escalated, a group of Cantonese merchants, scholars, and officials engaged in researching and developing Western ordnance and shipbuilding. ${ }^{32}$ The most famous action was that of Pan Shicheng (c. 1804-1873), who donated four large sailing ships in a hybrid Western and Cantonese style with a value of 19,000 tael each, and an American-type battleship of the same size for 43,000 tael. 33

28 Ibid., chap. 937, fol. $11 b$.

29 Huidian shili, chap. 938, fol. 9a.

30 Ibid., fol. 11 .

$31 \quad$ Ibid., fol. 13a, Daoguang 27 (1847).

32 Kennedy, The Arms of Kiangnan, p. 14.

33 Huidian shili, chap. 938, fol. 12b, Daoguang 24 (1844). According to Gideon Chen's study, Pan's first ship was finished in 1841 and had a copper bottom. See Gideon Chen, Lin Tse-hsü, p. 36. For the biographical data of Pan Shicheng, see Eminent Chinese of the Ch'ing Period, p. 6o6, and Chen Zehong, 'Pan Shicheng luekao', Guangdong shizhi 1995/Z1, pp. 69-7o. 
After this episode, entries in the Statutes are shorter and more widely interspersed and seem to be taken at random from the routine documentation of the Ministry of Public Works. Thus, in 1866, 14 new gunboats and sampans $^{34}$ built for the Shandong fleet and 36 new cannon boats built for Zhili in 1867 are mentioned. 35 The last entry, from 1878 , concerns the relocation of seven battleships from Shandong to Zhili. ${ }^{36} \mathrm{Li}$ Hongzhang in 1872 had suggested giving up traditional shipbuilding altogether, at least for navy ships. This idea was rejected by the Office of Foreign Affairs (Zongli yamen), ${ }^{37}$ but nevertheless the main government allocations after the $1860 \mathrm{~s}$ went to the development of steam navigation. In this field, the Ministry of Public Works was no longer involved.

\section{Locations of Government Shipyards}

Although the records of the locations of the government shipyards in the Huidian shili are not complete, they nevertheless reflect where the main centres of shipbuilding were from the beginning of the dynasty up to the mid-nineteenth century. A total of 44 shipyards established (or reestablished) between 1670 (Nanjing) and 1851 (Fengtian) are mentioned in the Collected Statutes (see Table 22). Some of them had branches; others were not included. No locations in the border regions Mongolia, Xinjiang, Tibet, Yunnan, Guangxi, and Guizhou, and the provinces Zhili, Gansu, Shanxi, Shaanxi, and Sichuan are mentioned. It seems improbable that not even temporary sites were set up in some of the provinces such as Zhili, Yunnan, and Guizhou. The end station of the Grand Canal at Tongzhou in Zhili, for instance, certainly had at least maintenance facilities. ${ }^{3}{ }^{8}$ However, the Collected Statutes also show evidence that ships for one province could be built in another province where materials and/or technical skills were more abundant. Generally speaking, the southern provinces constructed the ships for the north. Thus in Qianlong 1785, Jiangxi and Huguang provinces built 1,200 lighters for Zhili. However, there are also cases of an alternative, namely to send the timber to Tianjin and have the ships built there. In

34 Small cruisers, a general reference to open or half-decked boats of 30 to 40 feet (c. 9 to 12 meters) measurement. See Worcester, Junks and Sampans, p. 614.

35 Huidian, chap. 938, fol. 14b.

36 Ibid., fol. 15b/16a.

37 Kuo Ting-yee, 'Self-Strengthening', p. 510.

38 According to Hinton, Grain Tribute System, p. 11, ships were repaired by personnel of the altogether 67 transport stations weisuo along the Grand Canal and the related waterways. 
1822, the emperor endorsed a complaint by the provincial administrator Songyun, who reported that the lighters were not well built in Zhili because the craftspeople there were inexperienced. He suggested returning to the previous system and having the finished ships sent to Tianjin rather than the material. ${ }^{39}$ In another case, in the Qianlong reign, shipbuilders from Hubei and Hunan were sent to the Yunnan border to construct ships for a military expedition against Burma. ${ }^{40}$

\section{Mechanized Shipbuilding in the Era of Self-Strengthening}

The government modernization efforts of the last fifty years of the Qing dynasty were focused on armaments and shipbuilding. This was carried out in what is in the Western literature referred to as 'arsenals' and in Chinese as 'manufacturing bureaus' (zhizao ju) or 'machine manufacturing bureaus' (jiqi zhizao ju) and the Fujian Navy Yard (Fujian chuanzheng ju). Table 23 shows the number and various lines of production of these first sites of government-organized mechanization of craft branches. The broad designation 'manufacturing bureau', first coined by Li Hongzhang for the Jiangnan Arsenal, was chosen because production in these first mechanized workshops was intended not only for military but also, in a second step, for civilian purposes. ${ }^{41}$ At the same time, the arsenals were government offices administrated by traditional officials, who had to learn the ways of administration in mechanized production factories with a workforce of one to two-thousand and an important group of technicians, and with foreigners in leading technical positions. The idea that Western military technology must be adopted had already been formulated in the $1840 \mathrm{~s}$ by the elites that sought to remedy the situation of Chinese helplessness against Western military aggression. Wei Yuan (1794-1856), a scholar and mid-level administrator who cooperated with the Opium Commissioner Lin Zexu (1785-1850) in Canton, demanded this most clearly in the first Chinese work on Western countries, the Haiguo tuzhi (Illustrated treatise on the maritime kingdoms, 1843). He advocated the establishment of an arsenal and shipyard in Canton, the hiring of foreign experts as teachers

39 Huidian shili, chap. 935, fol. 7a, 16a.

40 Qingshigao, chap. 135, p. 3997. The place where the ships were built is given as Manmu 蠻

暮, probably a variant of Manmu 曼暮, which according to the Historical Atlas of China, vol. 8, p. 48, lay beyond the western border of Yunnan.

41 Kennedy, The Arms of Kiangnan, p. 47. 
on shipbuilding and navigation, and the inclusion of formal examinations of technical knowledge and navigational skills in the imperial examination system. ${ }^{42}$

The two main propagators of mechanized manufacturing in the era of self-strengthening were Zeng Guofan (1811-1872) and Li Hongzhang (18231901). Both Zeng and Li were high-level regional army commanders who had helped the Qing dynasty defeat the Taiping rebellion with their Hunan (Zeng) and Anhui (Li) armies and were therefore rewarded with the ranks of provincial governors. Zeng had supported Li's nomination, yet they differed in their priorities for modernizing China and for fighting imperialist enemies and internal adversaries of the Qing dynasty. Zeng Guofan placed the most emphasis on naval construction and marine development, while Li Hongzhang stressed arms manufacturing and the spread of mechanization also into fields of civilian manufacture. ${ }^{43}$ They found a compromise in setting up arsenals at different sites with specific tasks: the Jiangnan Arsenal in Shanghai for small arms, the Jinling (Nanjing) Arsenal for heavy ordnance, and the Tianjin Arsenal for powder and ammunition. One exception was that, at Zeng Guofan's personal suggestion, steamships were also built at the Jiangnan Arsenal. ${ }^{44}$ Another representative of the self-strengthening programme, Zuo Zongtang (1812-1885), a general of the Hunan army who had also fought the Taiping and later subdued the Moslem uprisings in Xinjiang and the Northwest, while acting as Governor-General of Fujian and Zhejiang, had proposed the establishment of a great shipyard at Fuzhou.

The earliest arsenal at Anqing in Anhui, Li Hongzhang's home province, took up pre-Taiping initiatives and experimented with steamship construction. In 1863, a small steamer was turned out, but its quality and speed were found wanting. The construction team had been entirely Chinese, and from this prototype it became clear that more expert Western knowledge and technical transfer were necessary. Therefore, foreigners were employed both in the Jiangnan Arsenal and the Fujian Navy Yard as directors or co-directors, technicians, teachers, and translators. In Shanghai the main influence was British and American, while in Fuzhou the advisors were French.

Other facilities that experimented with steamship technology were the Tianjin Arsenal at Dagu, established in 1880, and the official shipyard in Whampoa/Huangpu near Canton that was founded in 1885. Both had limited outputs of up to ten smaller warships. Finally, in 1890 a large dockyard for 
the repair and maintenance of the steamships of the North China fleet was built in Lüshun on Liaodong peninsula in Fengtian province. It was equipped with a 400 -foot stone dock and cost three million tael. A thousand workers were employed here, and between 1890 and 1894, $5^{8}$ steamships were repaired at the dock. However, in 1894 it was damaged in the Sino-Japanese War and was greatly reduced in scale. In 1897 it was occupied by Russia and after the Sino-Russian War in 1905 was taken over by Japan. 45

\section{Scope of Production of the Jiangnan Arsenal}

In 1865, the Jiangnan Arsenal was established by taking over an American shipyard, Thomas Hunt and Company (in Chinese known as Qiji tiechang) in the Hongkou district of the Shanghai foreign settlement, and by merging this with the two smaller Shanghai arsenals. The Shanghai Circuit Intendant was the principal director. Technical work was the domain of foreigners, who were either retained from the original employer or recruited later. ${ }^{46}$ In production and policy, the Jiangnan Arsenal followed what Thomas Kennedy has called a 'zigzag course of development'. ${ }^{47}$ This was due to the different priorities that its two founders, Li Hongzhang and Zeng Guofan, identified in terms of China's defence and their alternating influence on the Jiangnan Arsenal. In its first two years, the Arsenal produced small arms, as Li Hongzhang felt that arms and ammunition were the first priority for fighting internal enemies, in this case the Nian uprising in Central and Northern China. But after Li was called to replace and relieve Zeng Guofan as the commander of the North China pacification campaign, Zeng returned to his post of Governor-General of Jiangsu, Jiangxi, and Anhui and decided to initiate ship production at the Arsenal. With additional funds from the Shanghai maritime customs income, the Arsenal moved to a more spacious site at Gaochang miao on the banks of the Huangpu River, where a plant for steamship construction and a dry dock was built..$^{4}$ The first ship, the 6oo-ton steamer Dianji, was launched in August 1868. Subsequently, fourteen steamships were built until 1875 (see Table 23) ${ }^{49}$ In the years between 1867

45 Xin Yuan'ou, Zhongguo jindai, pp. 164-5;; Immanuel Hsü, 'Foreign Relations', p. 112; Liu Kwang-ching, 'Miltary Challenge', p. 256.

46 Kuo Ting-yee, 'Self-Strengthening', pp. 520-21.

47 Kennedy, The Arms of Kiangnan, p. 58.

48 Ibid., pp. 59/6o.

49 The 1983 History of the Jiangnan Arsenal, Jiangnan zaochuan chang changshi (hereafter cited as Jiangnan 1983), p. 39, table 2, based on Wei Yungong,Jiangnan zhizaoju, chap. 3, fol. 55a-b 
and 1875, 97 percent of the annual income of the Arsenal - ca. 450,000 tael - came from the Shanghai Maritime Customs, and 44 percent thereof was devoted to steamship construction and upkeep..$^{50}$

The first ships were provided with steam engines in wooden hulls. Technical advances were made in the improvement of the propeller system, which was introduced in the second vessel to replace the previous paddle wheel propulsion. On the third ship, the propeller was inserted at a more protected position below the waterline. Armaments also became increasingly sophisticated. Moreover, the shipyard experimented with twin propellers and armour-plated gunboats. All these vessels had a shallow draft and were well adapted for manoeuvring in harbours and rivers..$^{1}$

After Zeng Guofan's death, Li Hongzhang's influence prevailed, and as a result the shipbuilding programme of the Jiangnan Arsenal was stopped in 1875. In his function as Governor-General of Zhili since 1870, Li was also the responsible Commissioner for the Maritime Defence of North China. In the general discussion on defensive strategies to counter the menaces to the Qing dynasty from the separatist movement in Xinjiang and the threat to Taiwan from the Japanese (1874-75), Li had frequently complained that the ships built at the Jiangnan Arsenal were too expensive, not adapted to the needs of Chinese coastal defence, and inferior in quality to Western steamships. ${ }^{5^{2}}$ Moreover, he argued that the arsenals, and most of all the Jiangnan Arsenal, should focus their efforts on ordnance, ammunition, or shipbuilding and not extend their activities too broadly. Even his colleague Shen Baozhen (1820-1879), the Commissioner for Maritime Defence of South China who had previously been responsible for the Fujian Navy Yard, agreed that, at that moment, building up a defence fleet for Northern China had priority. Therefore, the government funds for maritime defence were all allocated to the North China Navy, and the Jiangnan Arsenal concentrated on the production of small weapons. Yet, since funds earmarked for the Northern navy had to be diverted to disaster relief, Li Hongzhang was not able to provide for the ironclad steamships as intended. Shen Baozhen thought that in this case,

('Steamships constructed in our shipyard'); Kennedy's statistics also take the more complete figures given by Wei Yungong in chap. 3, fol. 2a-6b, 16a, 27a, as well as archival sources into account. Kennedy, The Arms of Kiangnan, pp. 161/2, table 1. Meng Yue, 'Hybrid Science', p. 16, refers to eleven ships built in ten years (1868-1876), thereof ten warships, five wooden and five with iron hulls.

50 Kennedy, The Arms of Kiangnan, pp. 61-2.

51 Ibid., pp. 6o-1.

52 Kennedy, The Arms of Kiangnan, p. 95. 
the Southern Fleet should at least have some additional wooden hulled steamers for joint operations with the Northern Fleet. ${ }^{53}$ This eventually led to the construction of a few more ships in the Jiangnan Arsenal, most notably the Baomin, which was finished in $\mathbf{1 8 8 5}$. However, there are no reports of new ships being made between 1885 and 1905, although the steamship department was obviously retained during this period for maintenance. ${ }^{54}$ In 1905 , shipbuilding and arms construction were officially divided. The arsenal remained subordinate to the Ministry of War, while the shipyard became a commercial company that produced for profit and also supplied civilian customers. 55

\section{Scope of Production of the Fujian Navy Yard}

From the beginning, production at the shipyard of Mawei near Fuzhou was focused on shipbuilding. It was established in 1866 upon the initiative of Zuo Zongtang and subordinated to the Fujian Bureau for Naval Administration (or Fujian Navy Yard). Shen Baozhen, who had previously acted as provincial Governor of Jiangxi, led it until 1875, when he was appointed to the post of Governor-General of Jiangsu, Anhui, and Jiangxi and Commissioner of Trade for the Southern Ports. Funds provided for this venture were even bigger than those for the Jiangnan Arsenal. The original budget for Fuzhou provided for expenditures of three million tael over five years, but actually 5.25 million were spent in the first six-and-a-half years until July $1874,,^{6}$ exceeding the original estimates considerably. The Chinese government had contracted for the construction of 16 steamships with two French naval constructors, Prosper Giquel (1835-1886) and Paul d'Aiguebelle (1831-1875) $\cdot^{57}$ With a workforce of 45 foreign technicians, 2,00o Chinese craftsmen, and 900 labourers as well as a Chinese staff of 150 officials, this task could be nearly fulfilled: fifteen ships were launched within five years, among them ten between 1,000 and 1,450 tons..$^{8}$ Compared to the products of the Jiangnan Arsenal, the Fuzhou ships were considered to be of superior quality but still not up to the European standards of 1870 . Between 1875 and 1877 , only four ships were turned out, but one of them, the Weiyuan, a composite model

57 For a critical appraisal of Giquel's achievements, see Leibo, Transferring Technology to China.

$5^{8}$ Kuo Ting-yee, loc. cit. 
with an iron frame and wooden exterior, was equipped with a compound engine that had been built at the yard. ${ }^{59}$ Compound machines constituted a considerable technical advance through their efficient use of steam. They had been introduced in European and U.S. merchant ships after the 186os, but the British navy started to use them only after 1876 ; thereafter most other navies followed their example. ${ }^{60}$ Thus the production at Fujian was up to date with recent technological developments.

A big shock for the Chinese government, and particularly for the reformers, was the destruction of the entire Fuzhou fleet in the bombardment of the Mawei shipyard by the French marine in 1884 . This occurred in the course of the French expansion in Annam, where China had also claimed special rights that the French were not prepared to acknowledge. Historians today believe that it was not entirely due to French technological superiority that China lost the battle but also the result of insufficient coordination between the regional Chinese fleets and their commanders (the Northern Fleet based at Weihaiwei and Port Arthur, and the Southern Fleet based at Shanghai, Fuzhou, and Canton) as well as their lack of experience in modern naval strategy. ${ }^{61}$ In Benjamin Elman's analysis, the Chinese fleet had consisted of eleven wooden ships, and the nearby eight French vessels were ironclad, but the Chinese ships could have outmanoeuvred the heavier French ships. The Fuzhou fleet fought practically unassisted and was taken by surprise, since the French had attacked without warning. ${ }^{62}$

The losses of ships in this battle did not bring the Mawei shipbuilding project to a complete standstill, but it was certainly slowed down. This was also related to the death of its founder and main supporter, Zuo Zongtang, and the rise of the North China fleet under Li Hongzhang as the main Chinese navy. ${ }^{6}$ The overall production of the Fuzhou shipyard is given as 40 vessels built in the 46 years between 1866 and 1911, for which 19.21 million tael were used $-8.5^{2}$ for 'actual' construction costs and the rest for administration or downright 'waste'. ${ }^{64}$

\footnotetext{
59 Kuo Ting-yee, 'Self-Strengthening', p. 524, 533.

6o Radunz, 10o Jahre, pp. 150-152.

61 Elman, On their Own Terms, pp. 377-8. Kennedy, Arms of Kiangnan, p. 89. Meng Yue, 'Hybrid Science', p. 17 .

62 Elman, On their Own Terms, p. 378.

63 Ibid.

64 Entry 'Fuzhou chuanzheng ju Mawei chuanchang’ 福州船政局马尾船厂, in Chuanbo shuzi bowuguan, quoting from Shuiyun jishu cidian 水运技术词典 (Dictionary of water transport), p. 109.
} 
From the perspective of their output, the achievements of both shipyards regarding quantity and quality were not impressive compared to those Western countries where steam navigation had first been developed. A considerable part of the North Chinese and South Chinese steamship fleet had to be acquired from European manufacturers, who could produce cheaper and higher quality ships. However, the technological gap was narrowed, and industrialization and mechanization were started in these ventures.

\section{Schools for Technical Learning}

One of the great differences between traditional and modern government shipbuilding is that in the biggest shipyards, formal education and training was offered to some of the apprentices and artisans. The Chinese administrators had accepted the advice of their foreign consultants that steam technology and mechanized production of ordnance and ammunition could not be transmitted in informal on-the-job training. This type of education was part of the larger plans of the founders of the self-strengthening programme, namely to enable China to enter into the phase of domestic mechanized production in the military and civilian sectors with less reliance upon foreign goods. This entailed the theoretical acquisition of Western science and technology and its practical application. Each of these steps was highly problematical and controversial. Eventually, internal resistance against the modernization programmes waned as traditional elites became aware that after China's defeats in the 1884 conflict with France and the 1894/5 war with Japan, and the suppression of the Boxer Rebellion by international armed forces, the Chinese administrative and defensive system could not help but modernize.

Up to the present, the methods and impact of technology transfer and acquisition form one of the big issues in China's relation to the world. The beginnings of this in the 186os have been studied by a wide range of scholars, who all offer their specific assessments of this complicated process. ${ }^{65}$ For our topic, we need to come to a perspective on what difference the option for formal technical learning meant for the workforce in shipbuilding, the skilled artisans, and the apprentices.

65 The classical study is Biggerstaff, Earliest Modern Government Schools (1961), on which Kennedy, The Arms of Kiangnan, relies, and Bennet, John Fryer. More recent assessments are contained in Pong, Shen Pao-chen, Cornet, Etat et entreprises, Meng Yue, 'Hybrid Science', and Elman, On Their Own Terms. 
The earliest, largest and best-documented centres of learning in naval construction were at the Fuzhou Shipyard and the Jiangnan Arsenal, which will be presented in the following sections. ${ }^{66}$

\section{Technical Learning in the Fujian Navy Yard and the Jiangnan Arsenal}

As in naval production, the profile of the Fujian Navy Yard in education on shipbuilding stands out clearer than that of the Arsenal. The school of the Navy Yard was established in 1867 under the name Qiushi tang (Academy for the Search of Truth). Zuo Zongtang had planned that European engineers and technicians first be employed here as teachers for a period of five years. Thereafter, Chinese teaching and training staff would take over from them. Students should come from 'all levels of society', but the ideal target group were 'intelligent local boys with some literary knowledge'. ${ }^{67}$

About 100 pupils of age 14 enrolled initially. ${ }^{68}$ By 1873 , the apex of the school's activities, the French director Prosper Giquel reported that more than 300 students and apprentices from the various departments of the yard were registered. ${ }^{69}$ However, the dropout rate was high, even in the initial phase of the school. From 105 students admitted in 1867, only 39 remained at the end of $1873 \cdot{ }^{70}$ From 1874 to 1897 , the so-called 'period of self-management', the student numbers declined due to the curtailment of funds and less enthusiasm and support by the central government and provincial officials. Statistics from 1884 show a total of 188 students. In the early 1890 , school activities slowed down, but the school was not closed down. Between 1907 and 1913, no new students were recruited, and in 1913 it was reorganized into three separate schools for naval construction (zhizao xuexiao), the navy school (haijun xuexiao), and the technical school (yishu xuexiao $) \cdot 7^{11}$

66 At a later stage, elements of shipbuilding and navigation also taught at the Huangpu/ Whampoa 'School of Western Learning' (Xixue guan), founded in 1880 and subsequently renamed 'Guangdong shixue guan' (Guangdong School for Practical Studies). See Biggerstaff, Earliest Modern Government Schools, pp. 47-48, and Jiaoyu da cidian, vol. 10, p. 134.

67 Biggerstaff, Earliest Modern Government Schools, pp. 201, 205.

68 Kuo Ting-yee, 'Self-Strengthening', p. 532.

69 Biggerstaff, Earliest Modern Government Schools, p. 217; Giquel, Foochow Arsenal, p. 20.

70 Biggerstaff, Earliest Modern Government Schools, p. 210. Giquel, loc. cit. reports that the high attrition rate was due to six cases of death, and sixty pupils who were 'incapable' of following their courses and had been sent away.

71 Ibid., pp. 221, 226-241. 
Teaching and learning was realized at different levels and in various disciplines. In his account of the achievements of the school after seven years, director Giquel described that the school consisted of a 'French Division' and an 'English Division'. The French Division consisted of the Department for Naval Construction (zhizao xuetang), the Department for Design (huishi yuan), and the Department for Apprentices (yipu), while the English Division or Naval Academy had Departments for Theoretical Navigation (jiashixuetang) and Practical Navigation (lianchuan) as well as an Engine Room (guanlun xuetang ) $\cdot{ }^{72}$ Except for those from the Apprentice Department, the graduates from the French and English Divisions were supposed to become naval engineers and officers after full-time study of five years. The Apprentice Department provided part-time tuition for future foremen. It was set up later (1868) than the rest of the school, after it had become evident that mere on-the-job training for the workforce, such as carpenters, ironworkers, brass workers, and ship construction workers, created only a few able foremen..$^{73}$ Therefore, groups of ten to forty boys between the age of fourteen and seventeen from the operation divisions were to learn theoretical foundations for one-and-a-half hours before and after work. In the night and morning classes, these 'apprentices' (yitu) studied French, arithmetic, geometry, algebra, drawing, and took part in a course descriptive of engines. The course lasted three years or longer, and after graduation the young workers were expected 'to make a specification of the designs of an engine, to calculate the masses and weights of each of the parts; they are able, further, to describe the working of it in its most minute details. Two classes of about twenty students each had finished the course by 1874 . Director Giquel was particularly pleased about the achievements in this department, and the student statistics of 1884 show that the biggest group of the students, $3^{2}$ percent, followed the apprentice course. ${ }^{74}$ At the same time, during the production processes, on-the-job training for the regular workforce was given by French instructors during the initial phase and by their Chinese successors thereafter.

The English Division did not provide for a separate apprentice course. However, the full-time schooling in the engine room was targeted for students recruited from Hong Kong and Shanghai who had experience of iron working and a basic knowledge of English. This was desirable because few of the French, English, and at one period also German instructors spoke Chinese. 
The Jiangnan Arsenal also had technical curricula, but we do not know whether these were actually utilized. Regulations set up in 1870 provided for on-the-job training for workmen in the machine shops, shipyard, and arms factory. The instructors were to be the foreign and later Chinese engineers and machinists. Evening classes for workers and ship crews were also planned, and finally the curriculum of the Arsenal's famous and highly productive translation and interpretation department (Guang fangyan guan, Institute for the Dissemination of Foreign Languages, 1870) was to be expanded so as to include scientific and engineering departments. Foreign engineers were to teach two classes from 6 to 9 P.M., one in machinery and shipbuilding and the other on navigation and naval manoeuvres, for skilled workers, pilots, sailors, and ship mechanics who could follow the lectures with the help of interpreters. ${ }^{75}$

More formal training was offered to several dozen apprentices who in 1875 were sent to the Guang fangyan guan to study Western and Chinese subjects. Biggerstaff assumes that they were assigned to technical teaching departments. ${ }^{76}$ Later technical instruction outside the Guang fangyan guan was provided in a separate 'technical school' (Gongyi xuetang) established in 1898. It was planned to admit fifty students per year. Twenty of them were slotted to be children of Arsenal workers or artisans. One course was to last for four years. ${ }^{77}$ The technical school and the Guang fangyan guan were combined in 1905 to form a Gongye xuetang (industrial school), but soon afterwards they were reorganized into a primary, middle, and higher military school. ${ }^{78}$

What both schools had in common was the difficulty of acquiring technical knowledge in foreign languages. Moreover, at least in the first decades of the modernization initiatives, job perspectives after graduation were uncertain for the new engineers and naval officers if they could not stay on in their original schools. On a more general level, conservative elites doubted or even denied the necessity of modernization and modern education. Since the technical education offered in the Arsenals and the shipyard were so unorthodox, it had to be made attractive to the students by free tuition, board, and room and the promise of military or civilian titles in the traditional official system after graduation. This break with tradition highly irritated those in the Confucian establishment who saw graduation from these schools as a cheap shortcut to the coveted examination grades

Ibid., p. 168. Cornet, Etat et entreprises, p. 44, quoting from Bennet, John Fryer, pp. 9-11.

Biggerstaff, Earliest Modern Government Schools, p. 188.

Cornet, Etat et entreprises, p. 44.

Biggerstaff, Earliest Modern Government Schools, p. 193. 
that opened the way into officialdom. ${ }^{79}$ As a matter of fact, the Fujian Navy Yard engineers had difficulty finding jobs within the yard or the navy, and some of them sought employment with foreign firms or foreign consulates to work as translators or interpreters. ${ }^{80}$

Nevertheless, to the workers and apprentices, this systematic change in knowledge transfer must have had its challenging sides. The traditional chain of professional training, either from master to apprentice or from family elders to the next generation, was broken up. Theoretical scientific knowledge was made available to workers and artisans. The schools fostered skills that could be applied more widely than within the confines of the particular institution, and finally cultural transfer was offered from foreign teachers in foreign languages - all this was new and could benefit the pioneer generation of workers and technicians, if carefully and consequently carried out. That it was actively propagated by some of the Chinese statesmen as early as the 1870 s and 1880 s constitutes the big difference between shipbuilding and arms production and the other craft branches that were directly managed by the government.

\section{Appendix}

Table 21 List of documented state shipyards

\begin{tabular}{|c|c|c|c|c|}
\hline No. & Province & Location and name & $\begin{array}{l}\text { Reference to } \\
\text { construction of } \\
\text { grain ships }\end{array}$ & $\begin{array}{l}\text { Reference to } \\
\text { construction of } \\
\text { marine ships }\end{array}$ \\
\hline 1 & $\begin{array}{l}\text { Jiangnan (i.e. } \\
\text { Jiangsu) }\end{array}$ & $\begin{array}{l}\text { Jiangning (Nanjing) } \\
\text { Longjiang shipyard 龍 } \\
\text { 江船廠 }\end{array}$ & $\begin{array}{l}\text { Kangxi } 9 \text { (1670); } \\
\text { 're-established' in } \\
\text { Kangxi } 33 \text { (1694) }\end{array}$ & \\
\hline 2 & & $\begin{array}{l}\text { Huai'an Qingjiang 清江 } \\
\text { shipyard }\end{array}$ & $\begin{array}{l}\text { Kangxi } 33 \text { (1694) } \\
\text { 're-established' }\end{array}$ & $\begin{array}{l}\text { Personnel of Huai'an } \\
\text { shipyard reduced in } \\
\text { Qian-long } 24 \text { (1759) }\end{array}$ \\
\hline 3 & & $\begin{array}{l}\text { Huai'an Shandong } \\
\text { shipyard }\end{array}$ & Yongzheng 2 (1724) & \\
\hline 4 & & Suzhou & & $\begin{array}{l}\text { Kangxi } 57 \text { (1718), in } \\
\text { Yongzheng } 10 \text { (1732) } \\
\text { location moved to } \\
\text { Taicang zhou, Liuhe } \\
\text { defang 太倉州, 劉 } \\
\text { 河地方 }\end{array}$ \\
\hline
\end{tabular}

79 Biggerstaff, Earliest Modern Government Schools, p. 73; Cornet, Etat et entreprises, p. 44; Kuo Ting-yee, 'Self-strengthening', p. 529.

8o Biggerstaff, Earliest Modern Government Schools, p. 84. 


\begin{tabular}{|c|c|c|c|c|}
\hline No. & Province & Location and name & $\begin{array}{l}\text { Reference to } \\
\text { construction of } \\
\text { grain ships }\end{array}$ & $\begin{array}{l}\text { Reference to } \\
\text { construction of } \\
\text { marine ships }\end{array}$ \\
\hline 5 & & Yangzhou & & $\begin{array}{l}\text { Kangxi } 57 \text { (1718), in } \\
\text { Yongzheng } 9 \text { (1731) } \\
\text { location moved to } \\
\text { Jiangning }\end{array}$ \\
\hline 6 & & Zhenjiang & & Yongzheng 5 (1727) \\
\hline 7 & & Songjiang & & $\begin{array}{l}\text { Yongzheng } 5 \text { (1727), } \\
\text { in Yong-zheng } 10 \\
\text { (1732) moved to } \\
\text { Taicang zhou, Liuhe } \\
\text { difang }\end{array}$ \\
\hline 8 & & Shanghai & & $\begin{array}{l}\text { In Yongzheng } 9 \\
\text { (1731) moved to } \\
\text { Songjiang }\end{array}$ \\
\hline 9 & & $\begin{array}{l}\text { Jinshan } \\
\text { 'local shipyard' }\end{array}$ & Yongzheng 2 (1724) & \\
\hline 10 & & $\begin{array}{l}\text { Zhenjiang } \\
\text { 'local shipyard' }\end{array}$ & Yongzheng 2 (1724) & \\
\hline 11 & & $\begin{array}{l}\text { Suda 蘇大 [Sutai 蘇太]1 } \\
\text { 'local shipyard' }\end{array}$ & Yongzheng 2 (1724) & \\
\hline 12 & & $\begin{array}{l}\text { Zhenhai } \\
\text { 'local shipyard' }\end{array}$ & Yongzheng 2 (1724) & \\
\hline 13 & & $\begin{array}{l}\text { Outside Liuhe pai 劉 } \\
\text { 河牌外 }\end{array}$ & & Qianlong 24 (1759) \\
\hline 14 & & $\begin{array}{l}\text { Old shipyard at Haizhou } \\
\text { New Dike海州新壩 }\end{array}$ & & Qianlong 26 (1761) \\
\hline 15 & & $\begin{array}{l}\text { Xiazhen difang 夏鎮 } \\
\text { 地方 }\end{array}$ & $\begin{array}{l}\text { Qianlong } 31 \text { (1764) } \\
\text { ships for Xuzhou } \\
\text { pre-viously built } \\
\text { in Jiangning, now } \\
\text { new shipyard } \\
\text { established here }\end{array}$ & \\
\hline 16 & Shandong & Linqing & Qianlong 14 (1749) & \\
\hline 17 & & $\begin{array}{l}\text { Linqing, Hujia wan 胡 } \\
\text { 家灣 }\end{array}$ & Qianlong 47 (1782) & \\
\hline 18 & & $\begin{array}{l}\text { Jiaozhou (ships of } \\
\text { Southern Command) }\end{array}$ & & $\begin{array}{l}\text { Kangxi } 57 \text { (1718; only } \\
\text { repair) }\end{array}$ \\
\hline 19 & & $\begin{array}{l}\text { Dengzhou (ships of } \\
\text { Northern Command) }\end{array}$ & & $\begin{array}{l}\text { Kangxi } 57 \text { (1718; only } \\
\text { repair) }\end{array}$ \\
\hline 20 & Zhejiang & Renhe & Yongzheng 2 (1724) & Kangxi 57 (1718) \\
\hline 21 & & Qiantang & Yongzheng 2 (1724) & Kangxi 57 (1718) \\
\hline 22 & & Ningbo & & Kangxi 57 (1718) \\
\hline 23 & & Wenzhou & & Kangxi 57 (1718) \\
\hline 24 & & Zhapu & & Yongzheng 11 (1733) \\
\hline 25 & Fengtian & $\begin{array}{l}\text { On the Liao, Yidunhe, } \\
\text { and Huntongjiang rivers }\end{array}$ & Kangxi 22 (1683) & \\
\hline
\end{tabular}




\begin{tabular}{|c|c|c|c|c|}
\hline No. & Province & Location and name & $\begin{array}{l}\text { Reference to } \\
\text { construction of } \\
\text { grain ships }\end{array}$ & $\begin{array}{l}\text { Reference to } \\
\text { construction of } \\
\text { marine ships }\end{array}$ \\
\hline 26 & & Fengtian shipyard & & Xianfeng 1 (1851) \\
\hline 27 & Heilongjiang & & Kangxi 22 (1683) & \\
\hline 28 & Fujian & Fuzhou & & Kangxi 57 (1718) \\
\hline 29 & & Zhangzhou & & Kangxi 57 (1718) \\
\hline 30 & & Taiwan & & $\begin{array}{l}\text { Kangxi } 57 \text { (1718; } \\
\text { repair only) }\end{array}$ \\
\hline 31 & & Quanzhou & & Yongzheng 7 (1729) \\
\hline 32 & & Xiamen & & $\begin{array}{l}\text { In Qianlong } 1 \text { (1736), } \\
\text { the official shipyard } \\
\text { of Quanzhou was } \\
\text { moved to Xiamen }\end{array}$ \\
\hline 33 & Guangdong & $\begin{array}{l}\text { Guangzhou Henan } \\
\text { difang 河南地方 }\end{array}$ & & Qianlong 17 (1752) \\
\hline 34 & & $\begin{array}{l}\text { Chaozhou Anbu difang } \\
\text { 庵埠地方 }\end{array}$ & & Qianlong 17 (1752) \\
\hline 35 & & $\begin{array}{l}\text { Gaozhou Zhikai difang } \\
\text { 芷节地方 }\end{array}$ & & $\begin{array}{l}\text { Before Qianlong } \\
8 \text { (1743); then } \\
\text { location be moved } \\
\text { to Guangzhou; } \\
\text { mentioned again in } \\
\text { Qianlong } 17 \text { (1752) }\end{array}$ \\
\hline 36 & & $\begin{array}{l}\text { Qiongzhou, Hainan, } \\
\text { Haikou difang 海南海 } \\
\text { 口地方 }\end{array}$ & & Qianlong 17 (1752) \\
\hline 37 & & $\begin{array}{l}\text { Longmen difang 龍門 } \\
\text { 地方 }\end{array}$ & & Qianlong 2 (1737) \\
\hline 38 & Hubei & Wuchang & Yongzheng 2 (1724) & \\
\hline 39 & & Hanyang & Yongzheng 2 (1724) & \\
\hline & Anhui & Anqing 'local shipyard' & Yongzheng 2 (1724) & \\
\hline 41 & & Xin'an 'local shipyard' & Yongzheng 2 (1724) & \\
\hline 42 & & $\begin{array}{l}\text { Xuanzhou 'local } \\
\text { shipyard' }\end{array}$ & Yongzheng 2 (1724) & \\
\hline 43 & & Jianyang 'local shipyard' & Yongzheng 2 (1724) & \\
\hline 44 & Jiangxi & $\begin{array}{l}\text { 'All guard stations should } \\
\text { establish local shipyards' }\end{array}$ & Yongzheng 2 (1724) & \\
\hline
\end{tabular}

Source: This list is based on the chapters 202 (Hubu:Caoyun), 935 (Gongbu: Chuanzheng: Liangchuan), and 936 to 938 (Gongbu: Chuanzheng: Zhanchuan) of the Collected Statutes (Huidian shili), which do not give a systematic geographical coverage of all official shipyards in the provinces, but they contain a compilation of relevant memorials, decisions, and edicts concerning grain ships (liangchuan 糧船) and battleships (zhanchuan 戰船).

${ }^{1}$ The photomechanic reprint edition of Wenxing shuju has the character 大, the scanned version in the online full text database Chinese Text Project has 太. See Huidian shili, chap. 935, fol. 4b, and http://ctext.org/library.pl?if=en\&file=27560\&page=9\&editwiki=587292\#box $(166,384,0,2)$. 


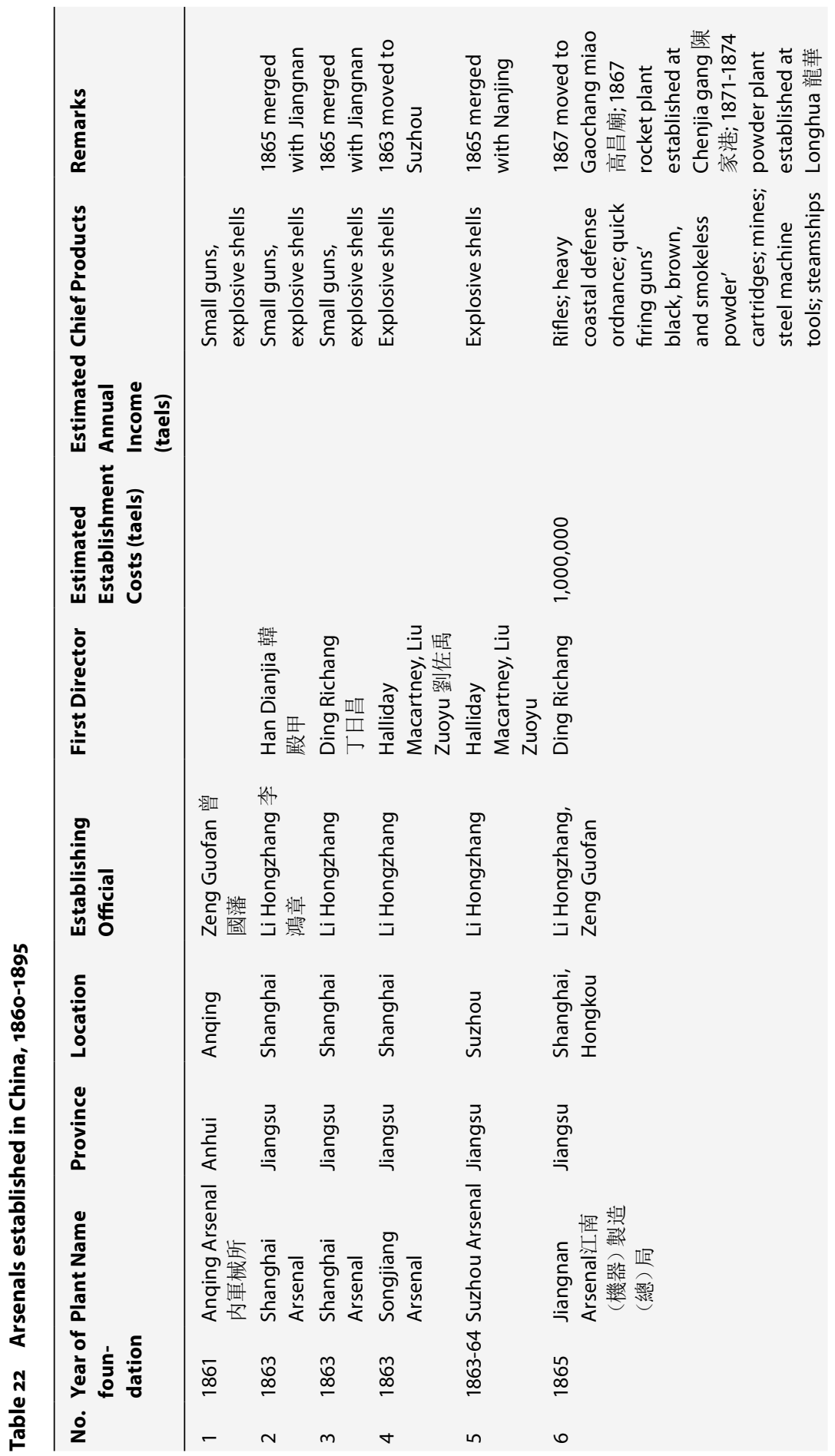




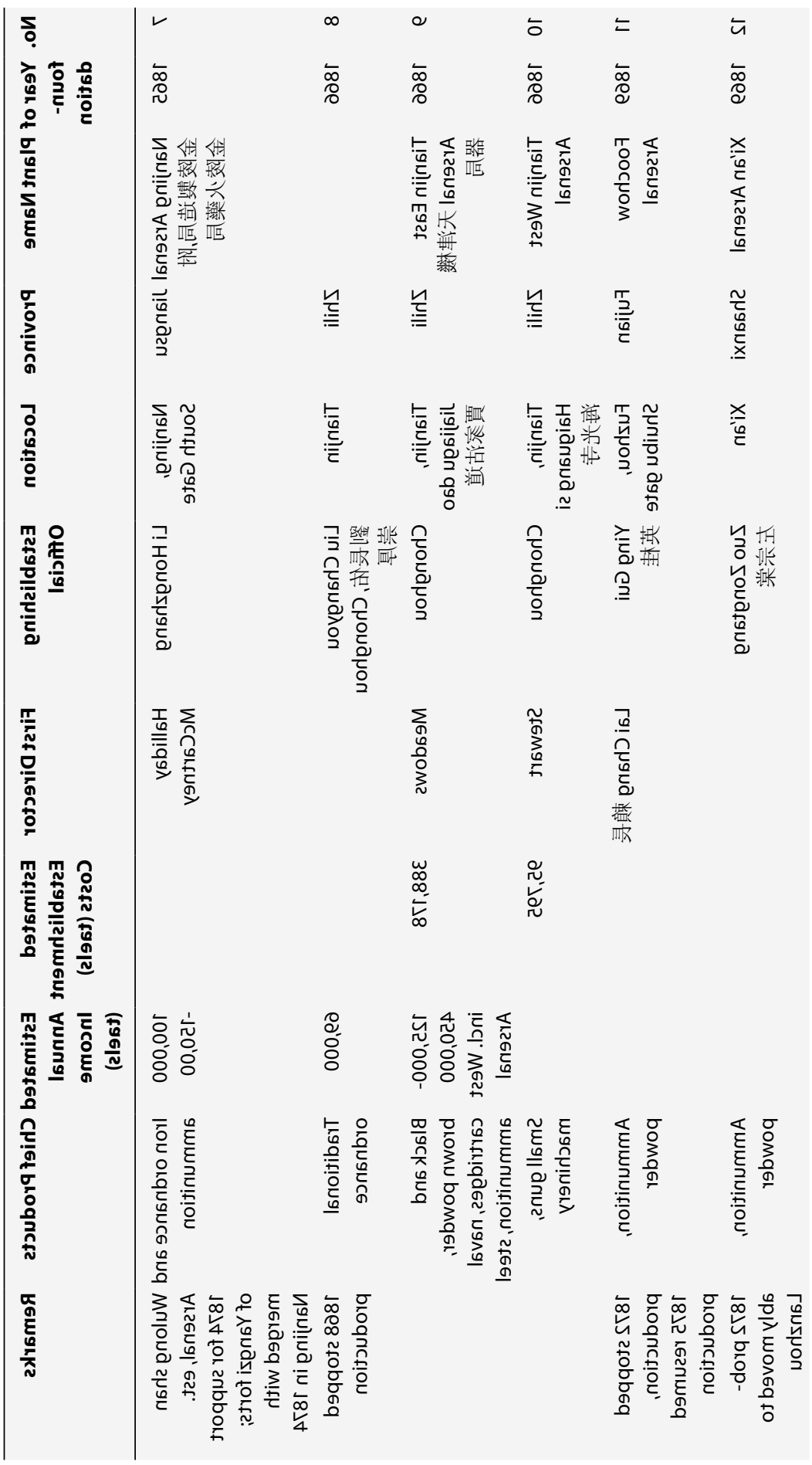




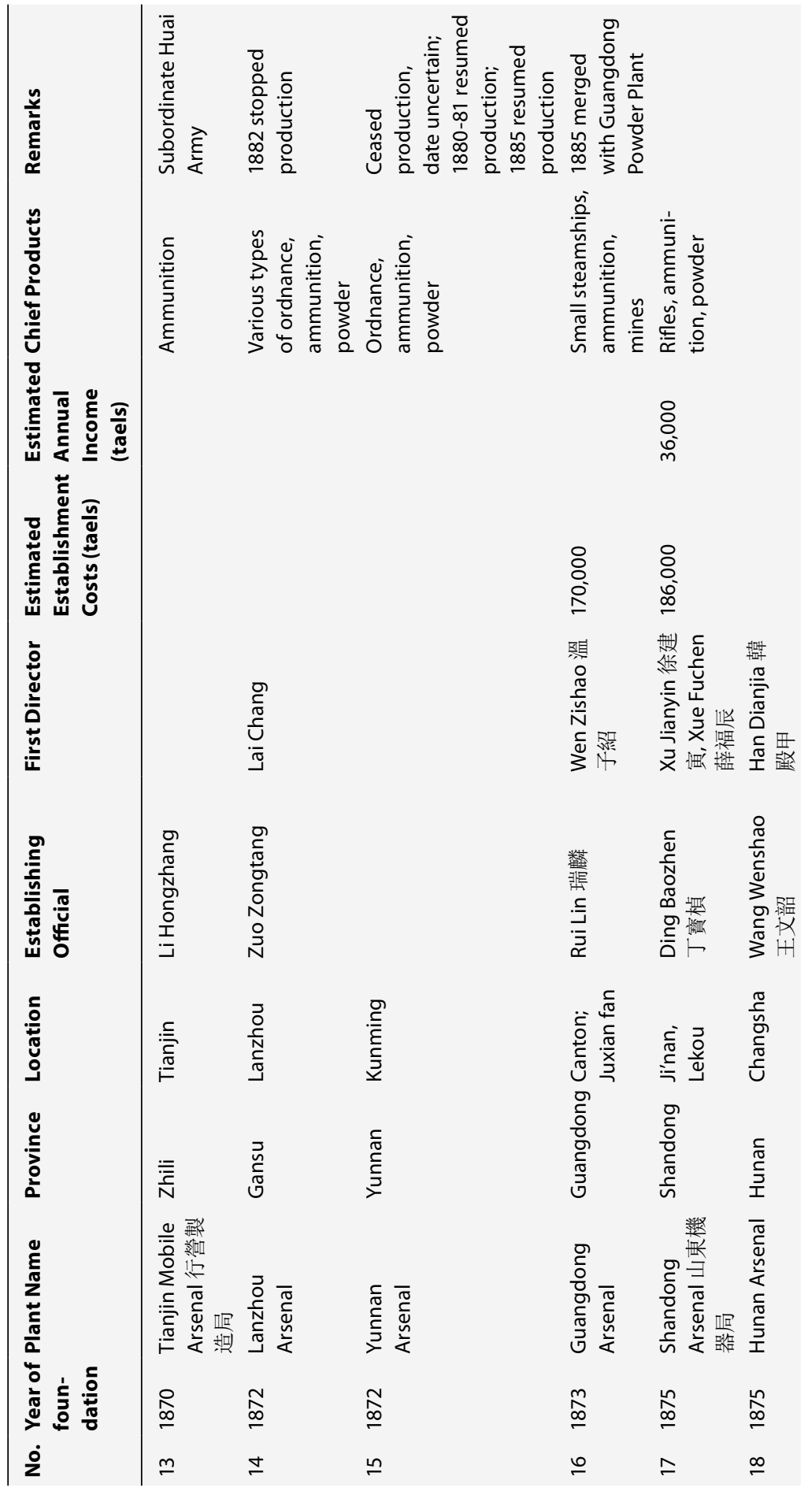




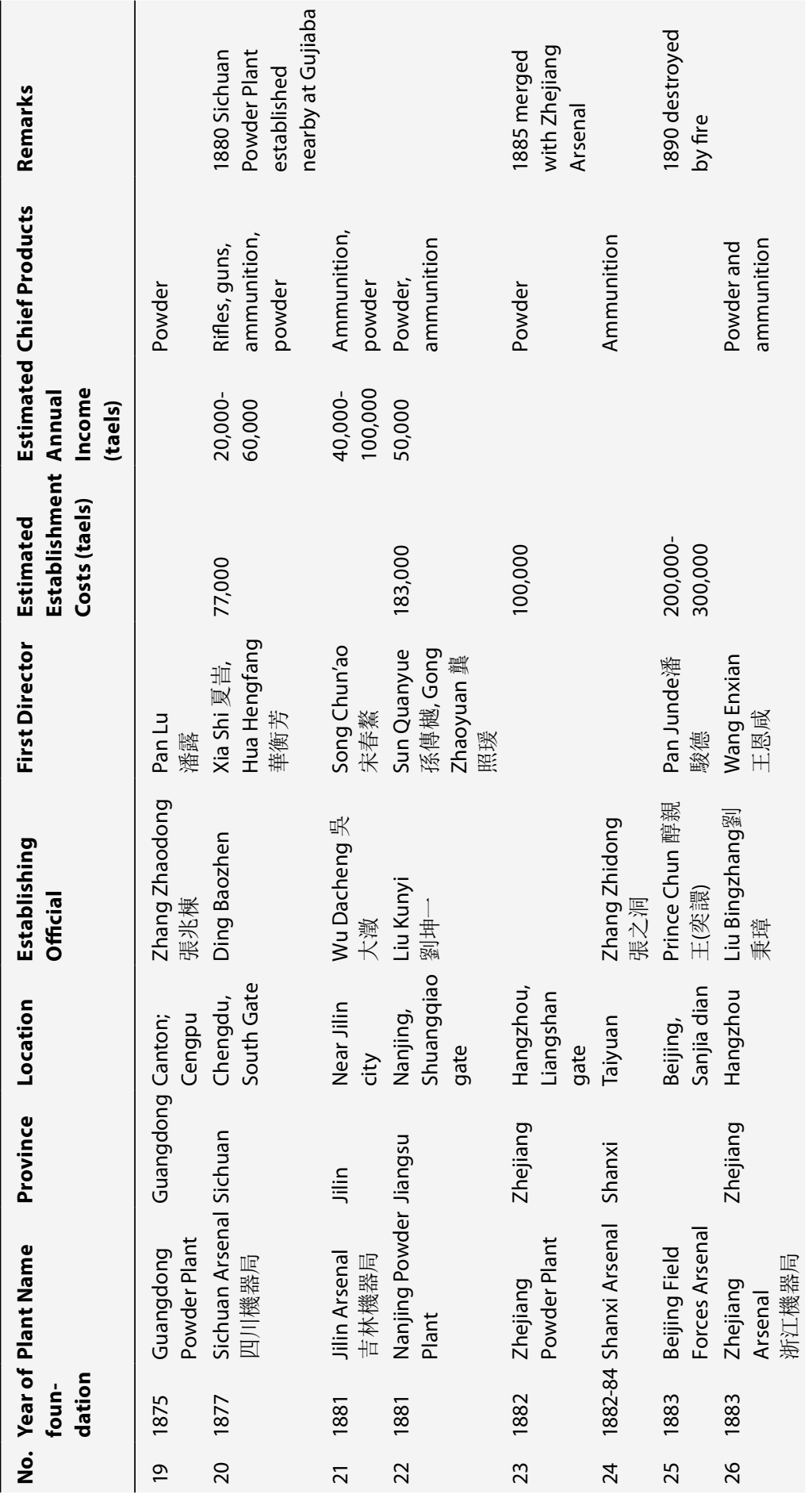




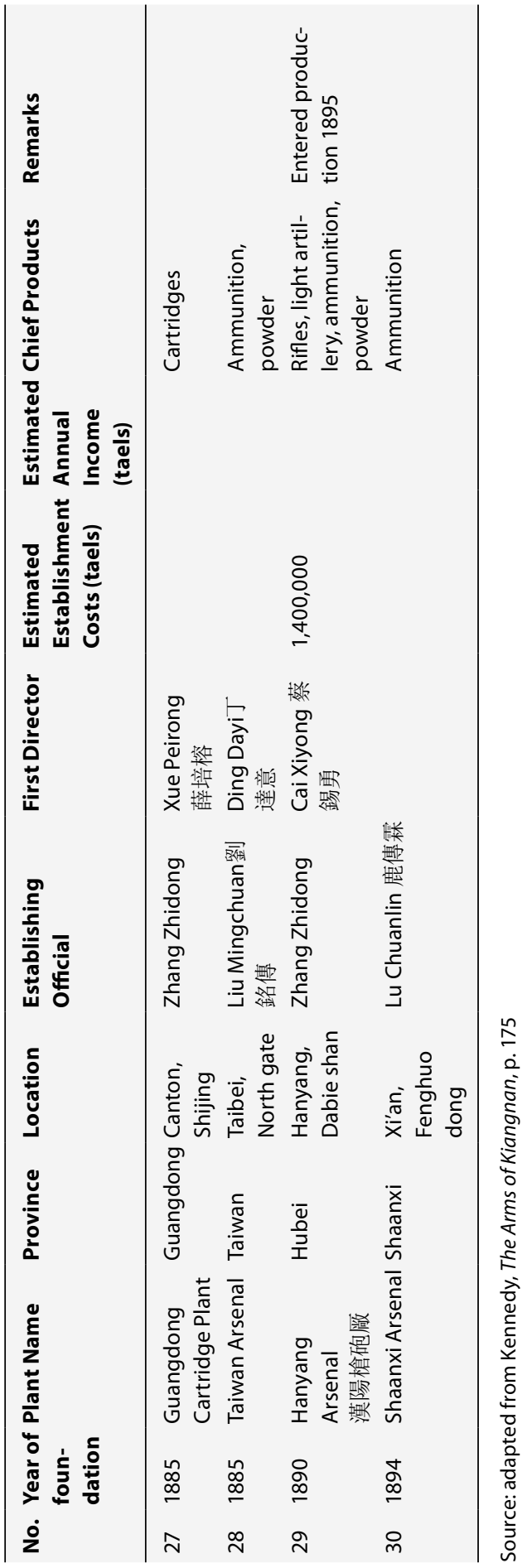


Table 23 Ships built at the Jiangnan Arsenal

\begin{tabular}{|c|c|c|c|c|c|c|c|c|}
\hline No & $\begin{array}{l}\text { Date } \\
\text { Completed }\end{array}$ & Name & $\begin{array}{l}\text { Length } \\
\text { (chi/ } \\
\text { metre) }\end{array}$ & $\begin{array}{l}\text { Width } \\
\text { (chi/ } \\
\text { metre) }\end{array}$ & $\begin{array}{l}\text { Horse } \\
\text { Power }\end{array}$ & $\begin{array}{l}\text { Displace- } \\
\text { ment } \\
\text { (tons) }\end{array}$ & Description & $\begin{array}{l}\text { Construc- } \\
\text { tion Costs } \\
\text { (tael) }\end{array}$ \\
\hline 1 & 1868 Aug. & $\begin{array}{l}\text { Dianji } \\
\text { 恬吉 }\end{array}$ & $\begin{array}{l}185 / \\
59.2\end{array}$ & $\begin{array}{l}27.2 / \\
8.7\end{array}$ & $\begin{array}{l}150 / \\
{[392]}\end{array}$ & 600 & $\begin{array}{l}\text { Wooden hull, } \\
\text { paddle wheel }\end{array}$ & 81,397 \\
\hline 2 & $\begin{array}{l}1869 \text { May- } \\
\text { June }\end{array}$ & $\begin{array}{l}\text { Caojiang } \\
\text { 操江 }\end{array}$ & $\begin{array}{l}180 / \\
57.6\end{array}$ & $\begin{array}{l}27.8 / \\
8.9\end{array}$ & $\begin{array}{l}80 / \\
{[425]}\end{array}$ & 640 & $\begin{array}{l}\text { Wooden hull, } \\
\text { propeller }\end{array}$ & 83,306 \\
\hline 3 & $\begin{array}{l}1869 \\
\text { Aug. } 25\end{array}$ & $\begin{array}{l}\text { Cehai } \\
\text { 測海 }\end{array}$ & $\begin{array}{l}175 / \\
56\end{array}$ & $\begin{array}{l}28 / \\
8.9\end{array}$ & $\begin{array}{l}125 / \\
{[431]}\end{array}$ & 600 & $\begin{array}{l}\text { Wooden hull, } \\
\text { propeller }\end{array}$ & 82,736 \\
\hline 4 & $\begin{array}{l}1870 \\
\text { Sept.-Oct. }\end{array}$ & $\begin{array}{l}\text { Weijing } \\
\text { 威靖 }\end{array}$ & $\begin{array}{l}205 / \\
65.6\end{array}$ & $\begin{array}{l}30.6 / \\
9.8\end{array}$ & $\begin{array}{l}150 / \\
{[605]}\end{array}$ & 1,000 & $\begin{array}{l}\text { Wooden hull, } \\
\text { propeller }\end{array}$ & 118,031 \\
\hline 5 & 1872 May 24 & $\begin{array}{l}\text { Zhen'an } \\
\text { 鎮安, } \\
\text { changed } \\
\text { to Hai'an } \\
\text { 海安 }\end{array}$ & $\begin{array}{l}300 / \\
96\end{array}$ & $\begin{array}{l}42.0 / \\
13.4\end{array}$ & $\begin{array}{l}500 / \\
{[1800]}\end{array}$ & 2,800 & $\begin{array}{l}\text { Wooden hull, } \\
\text { propeller }\end{array}$ & 355,190 \\
\hline 6 & By July 1872 & & & & & & $\begin{array}{l}\text { Armour plate, } \\
\text { twin propeller }\end{array}$ & 5,360 \\
\hline 7 & By July 1872 & & & & & & $\begin{array}{l}\text { Armour plate, } \\
\text { twin propeller }\end{array}$ & See below \\
\hline 8 & By 1874 Jan. & & & & & & $\begin{array}{l}\text { Armour plate, } \\
\text { twin propeller }\end{array}$ & $\begin{array}{l}13,599 \\
\text { Including } \\
\text { above } \\
\text { vessel }\end{array}$ \\
\hline 9 & 1873 Dec. 23 & $\begin{array}{l}\text { Yuyuan } \\
\text { 馭遠 }\end{array}$ & $\begin{array}{l}300 / \\
96\end{array}$ & $\begin{array}{l}42 / \\
13.4\end{array}$ & $\begin{array}{l}500 / \\
{[1800]}\end{array}$ & 2800 & $\begin{array}{l}\text { Wooden hull, } \\
\text { propeller }\end{array}$ & 318,717 \\
\hline 10 & $1874-75$ & $\begin{array}{l}\text { Jin'ou 金 } \\
\text { 甌 }\end{array}$ & $\begin{array}{l}105 / \\
33.6\end{array}$ & $\begin{array}{l}20 / \\
6.4\end{array}$ & 200 & & $\begin{array}{l}\text { Ironclad } \\
\text { (Monitor } \\
\text { class) }\end{array}$ & 62,586 \\
\hline 11 & $1874-75$ & & & & & & $\begin{array}{l}\text { Armour plate, } \\
\text { twin Propeller }\end{array}$ & 8,960 \\
\hline 12 & $1874-75$ & & & & & & $\begin{array}{l}\text { Armor plate, } \\
\text { twin propeller }\end{array}$ & 10,943 \\
\hline 13 & $1874-75$ & & & & & & $\begin{array}{l}\text { Motorized } \\
\text { sampan }\end{array}$ & 990 \\
\hline 14 & $1874-75$ & & & & & & $\begin{array}{l}\text { Foreign style } \\
\text { sailing vessel }\end{array}$ & 57,005 \\
\hline 15 & 1881 & & $\begin{array}{l}136 / \\
43.5\end{array}$ & $\begin{array}{l}22 / \\
7\end{array}$ & 650 & 400 & $\begin{array}{l}\text { Twin } \\
\text { propeller }\end{array}$ & \\
\hline 16 & 1885 & $\begin{array}{l}\text { Baomin } \\
\text { 保民 }\end{array}$ & $\begin{array}{l}225.3 / \\
72\end{array}$ & $\begin{array}{l}36 / \\
11.05\end{array}$ & 1900 & & $\begin{array}{l}\text { Steel } \\
\text { armoured }\end{array}$ & 223,800 \\
\hline
\end{tabular}

Source: adapted from Kennedy, The Arms of Kiangnan, p. 161/2, table 1, and Jiangnan zaochuan chang changshi, p. 39, table 2. The figures given for horsepower vary for all except two ships. Figures in brackets are from Jiangnan zaochuan chang changshi. 
